\title{
The Imidazoline Receptor Antagonists Idazoxan and Efaroxan Improve the Spatial and Reference Memory in Rats
}

\author{
GABRIELA RUSU-ZOTA ${ }^{1}$, ANDREI LUCA ${ }^{2,3 *}$, GABRIELA DUMITRITA STANCIU3 ${ }^{3}$, VICTORITA SORODOC ${ }^{4}$, \\ MARIA MAGDALENA LEON-CONSTANTIN 5 , BOGDAN STOICA ${ }^{6}$, CRISTINA GALES7, TEODORA ALEXA-STRATULAT ${ }^{8}$ \\ ${ }^{1}$ Grigore T. Popa University of Medicine and Pharmacy, Department of Pharmacology, Clinical Pharmacology and Algesiology, 16 \\ Universitatii Str., 700115, lasi, Romania \\ ${ }^{2}$ Grigore T. Popa University of Medicine and Pharmacy, Department of Pneumology,16 Universitatii Str., 700115, lasi, Romania \\ ${ }^{3}$ Center for Advanced Research and Development in Experimental Medicine (CEMEX), Str9-13 M. Kogalniceanu Str., 700454, Iasi, \\ Romania \\ ${ }^{4}$ Grigore T. Popa University of Medicine and Pharmacy, Department of Internal Medicine, 16 Universitatii Str., 700115, Iasi, \\ Romania \\ ${ }^{5}$ Grigore T. Popa University of Medicine and Pharmacy, Department of Medical Semiology, 16 Universitatii Str., 700115, Iasi, \\ Romania \\ ${ }^{6}$ Grigore T. Popa University of Medicine and Pharmacy, Faculty of Medicine, Department of Biochemistry, 16 Universitatii Str., \\ 700115, lasi, Romania \\ ${ }^{7}$ Grigore T. Popa University of Medicine and Pharmacy, Department of Histology, 16 Universitatii Str., 700115, lasi, Romania \\ ${ }^{8}$ Grigore T. Popa University of Medicine and Pharmacy, Department of Medical Oncology-Radiotherapy, 16 Universitatii Str., \\ 700115, lasi, Romania
}

\begin{abstract}
Experimental studies and clinical trials revealed the complex interconnections between imidazoline system and various other mediators such as epinephrine, norepinephrine; thus, explain their involvement in the pathophysiological mechanisms of different motor, behavioral and cognitive disturbances. In this study, we tested the influence induced by idazoxan and efaroxan on the cognitive performances in rats. Groups of 6 adult male Wistar rats were treated intraperitoneally according to the following protocol: group I (Control): distilled water 0.3 ml/100g; group II (IDZ): $3 \mathrm{mg} / \mathrm{kg}$ idazoxan and group III (EFR): $1 \mathrm{mg} / \mathrm{kg}$ efaroxan. The effects of the imidazoline receptor antagonists on the rats cognitive functions were assessed using the radial-arm maze, in order to count the time spent into the arms, the number of baited arms visited, but previously explored (working memory errors); the time taken to consume all baits and the number of entering in non-baited arms (reference memory errors). The data were expressed as mean +/- standard deviation, and statistically analyzed using SPSS version 17.0 Software for Windows, followed by ANOVA one-way method. The administration of IDZ, as well as of EFR was accompanied by a substantial diminution in the number of working memory errors, and the period of time to consume all baits, statistically significant $(p<0.01)$ compared to control group. The use of these two imidazoline receptors antagonists resulted in a considerable decrease in the reference memoryerrors number, statistically significant $(p<0.01)$ compared to the group treated with distilled water. The influence of IDZ on the evaluated parameters was more accentuated than the effects induced by EFR in all sessions of testing, in this behavioral experimental model. Our findings indicate that treatment with both imidazoline receptor antagonists, idazoxan and efaroxan was associated by a facilitation of the short-term memory retention, an enhancement of discriminative spatial learning, and an improvement of long-term memory performance in radial arm maze in rats.
\end{abstract}

Keywords: imidazoline receptors antagonists, spatial and reference memory, rats

Imidazoline is a class of heterocycles formally derived from imidazole's by the reduction of one of the two double bonds. Three isomers are known, 2-imidazolines, 3imidazolines, and 4-imidazolines. The 2- and 3-imidazolines contain an imine center, whereas the 4-imidazolines contain an alkene group [1]. Discovered in 1984, imidazoline receptors (I1 receptor appears to be a $\mathrm{G}$ proteincoupled receptor involved in inhibition of the sympathetic nervous system to lower blood pressure; 12 receptor modulate the level of central monoamines, with potential antidepressant and antinociceptive activity and 13, regulates insulin secretion from pancreatic beta cells) are both central and peripheral, influencing several physiological and pathological processes [1]. Imidazoline system is one of the major structures involved in the functioning of the human body: inhibitory sympathetic action; neuroprotective effects and mediation of the nociceptive sensitivity, insulinotropic activity, mediation of the addictive phenomenon and antidepressant activity [2] . Literature data have revealed the implication of imidazoline receptors in some pathophysiological (regulation of adipose tissue formation, feeding behavior) and pathological pathways involved in epilepsy and processes of neoplastic cell transformation $[3,4]$. The potent neurotransmitter of imidazoline system, agmatine contributes in the mediation of the body's response to stress, in analgesia, drug addiction, withdrawal syndrome and in neuroprotection [4-6].

Deepening investigations related to the participation of substances acting on the imidazoline receptors, on behavior, memory, locomotor activity, is a starting point for getting new information about the pathophysiological mechanisms of spontaneous behavior disturbances and 
cognitive disorders [7-9]. The results of investigations on different imidazoline agonists have been reported, butfew of these compounds possess selective activity on the imidazoline receptors. Some potent imidazoline receptor antagonists were discovered, but their clinical use is not implemented yet. Previous researches conducted on laboratory animals have shown that efaroxan and idazoxan completely blocked the anti-compulsive effects of agmatine, suggesting the involvement of imidazoline receptors in anxiety and in obsessive-compulsive disorders $[10,11]$.

Other experimental investigations have revealed that agmatine and the imidazoline receptors may be important therapeutic targets for the treatment of depressive disorders, after finding that efaroxan and idazoxan blocked the effects of antidepressant drug bupropion and antagonized the synergistic activity of its association with agmatine $[3,12]$.

The results reported so far in this field are few, and, in most cases insufficient. Studying the possibilities of pharmacological influence of the motor spontaneous behavior and the cognitive functions through the imidazoline system is currently an interesting research area. Finding in the literature of the diversity and often controversial data regarding the influence induced by the imidazoline agents on motor behavior and spatial memory, justifying the present experimental researches, trying to elucidate the pharmacodynamics effects of two imidazoline receptor antagonists idazoxan and efaroxan, and to assess their involvement in mediating spontaneous behavior and cognitive functions in laboratory animals.

We aimed to evaluate the effects of two imidazoline receptors antagonists idazoxan and efaroxan on the spatial memory performances in rats.

\section{Experimental part}

Material and method

All experimental procedures were conducted in accordance with the European Communities Council Directive 2010/63/EU on the Protection of Animals Used for Scientific Purposes, the Committee for Research and Ethical Issues of International Association for the Study of Pain guidelines and were approved byUniversity of Medicine and Pharmacy Grigore T. Popa Institutional Animal Care and Use Committee. Every effort was made to minimize the number of animals used and the potential distress. All animals were euthanized at the end of the experiment in accordance with the legislation.

\section{Animals and experimental protocol}

All reagents were purchased from Sigma Aldrich $\mathrm{GmbtH}$, Steinheim, Germany; and included idazoxan and efaroxan, were dissolved in distilled water, the solutions being prepared extemporaneously.

Young healthy adult (150-200g, 4-6 months) male W istar rats were used in the present study. Animals were housed of 2 individuals per cage, in climate-controlled $\left(20 \pm 4^{\circ} \mathrm{C}\right.$ elsius, $50 \pm 5 \%$ relative humidity, $12 \mathrm{~h}$ light/dark cycles) facility, individually ventilated cages containing shaving bedding material, with regular rodent chow and water ad libitum. Groups of 6 rats were injected intraperitoneally with the following formulations: group I (Control): distilled water $0.3 \mathrm{~mL} / 100 \mathrm{~g}$ body weight; group II (IDZ): $3 \mathrm{mg} / \mathrm{kg}$ body weight idazoxan; group III (EFR): 1 $\mathrm{mg} / \mathrm{kg}$ body weight efaroxan.

The involvement of imidazoline agents in the maintenance of spatial cognition, the radial eight-arm maze, was used. This behavioral test was designed to assess the animal's reference and working memory performances, being included in the same group with other specific behavioral models (Y-maze, T-maze, elevated arm maze, swimming test) [14-17].

This apparatus consists of a central platform (with 30 $\mathrm{cm}$ diameter), elevated above the floor, and eight identically radial arms. On the distal part of each arm, a detachable recessed cup can be placed, or removed by covered up. The scheme of this maze ensures that after searching for food at the end of each arm, the rat is forced to reach the central platform, before starting a new exploration. The animal permanently has eight potential choices.

Supplementary, a video camera placed above the device and connected to a computer in other room, was used to evaluate the animal's behavior without distressing it. The sessions of testing, were video-recorded and successively analyzed by an independent researcher, blinded to the treatment circumstances. After preliminary acclimation to the testing room conditions, there were two daily training sessions of separately five minutes, in which the rat was allowed to move freely through the maze without food. Thereafter, the animal was motivated to explore a single arm for discovering a piece of cheese as the bait. Before each trial, the selected arms were baited with a piece of cheese, placed in the special food cups. All eight arms of the maze were reachable, but, four of them, were arbitrarily baited. The arms were not re-baited during the trial. At the beginning of the evaluation, the rat was positioned in the central area, allowed to explore the maze and to locate the food in 5 minutes testing sessions. [18,19]. Revisits of the arms previously entered were scored as errors. The trial was interrupted when the animal visited all eight arms.

The following parameters were evaluated: the total number of arms, explored during five minutes; the number of new arms visited during the first eight entries in an nonbaited arm; the number of entering in an arm containing bait, but previously visited (working memory errors); the number of non-baited arms explored (reference memory errors); the time taken to consume all baits.

In this behavioral experimental model, the decreasing in errors of working memory (relevant elements for measuring short-term memory) signifies a facilitator effect on the short-term memory $[19,20]$. The reducing of time required for the consumption of all baits corresponds to an enhancement of the discriminative spatial memory by increasing the accuracy of choosing the arm in radial arm maze $[18,21,22]$. The decreasing in the number of reference errors (important elements to quantify the longterm memory), corresponds to a favorable effect on the long-term memory [23-25].

The data were presented as arithmetic mean \pm standard deviation (SD) of mean, and analyzed using SPSS program for Windows 10, version 17.0, ANOVA method. P- values less than 0.05 were statistically significant compared to control group.

\section{Results and discussions}

The treatment of IDZ $(3 \mathrm{mg} / \mathrm{kg})$ and with EFR $(1 \mathrm{mg} / \mathrm{kg})$ slightly prolonged the time spent in the arms, but statistical non-significant comparing with the group treated with distilled water in each session of testing in radial arm maze in rats (fig. 1).

The effects of IDZ to extend the time spent in the arms were sizable more accentuated than of EFR within the experiment (fig. 1). The use of IDZ was associated with the reduction in the number of the baited arms visited, but 


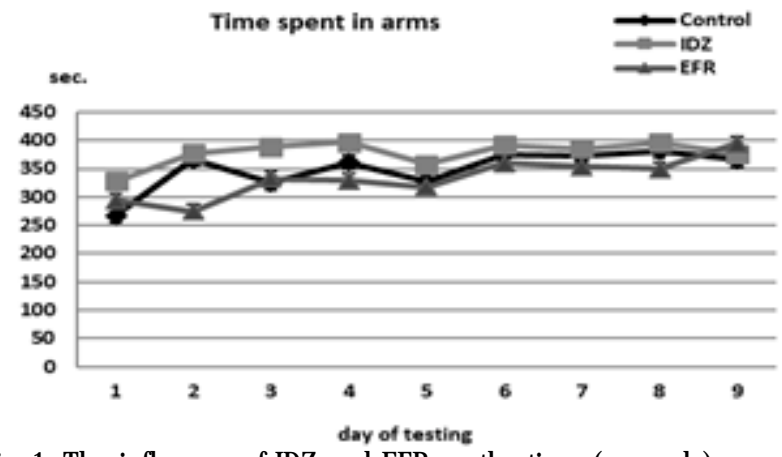

Fig. 1. The influence of IDZ and EFR on the time (seconds) spent in the arms, in radial arm maze test. Values were presented as mean \pm SD of time spent in the arms.

already explored, statistically significantly $(* * p<0.01)$ compared to control group (fig. 2).

The administration of EFR reduced the number of errors related to finding the rewards, statistically significant $(* * p<0.01)$ compared with the group treated with distilled water in the third, fourth and in the last four sessions of testing in radial arm maze (fig. 2).

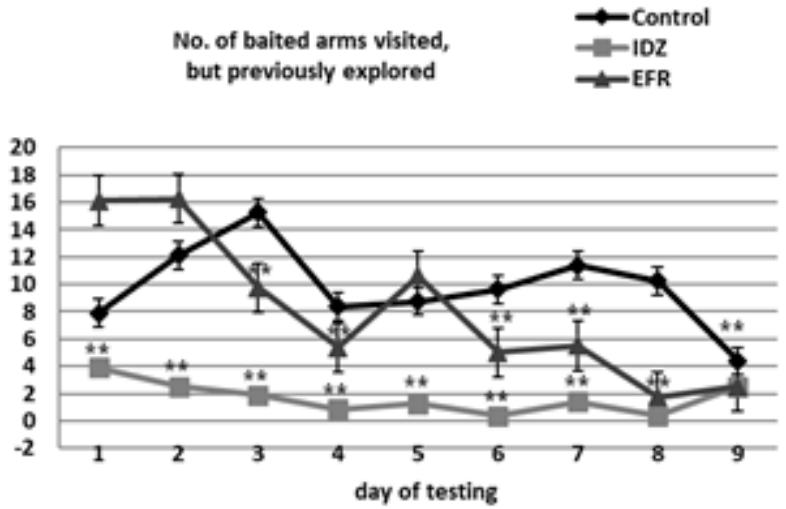

Fig. 2. The influence of IDZ and EFR on the number of baited arms visited, but previously explored in radial arm maze test. Values were presented as mean \pm SD of the number of baited arms visited, but previously explored. ${ }^{* *} p<0.01$ vs control

The effects of IDZ on the decreasing in the number of baited arms visited, but previously chosen, were more intense than of EFR in this behavioral experimental model in rats (fig. 2). Intraperitoneal injection of IDZ, respectively of EFR did not substantially modify the number of consumed baits, compared to distilled water group in radial arm maze (fig. 3).

The effects of IDZ the number of consumed baits were comparable to those of the EFR in all moments of testing in the experiment (fig. 3).

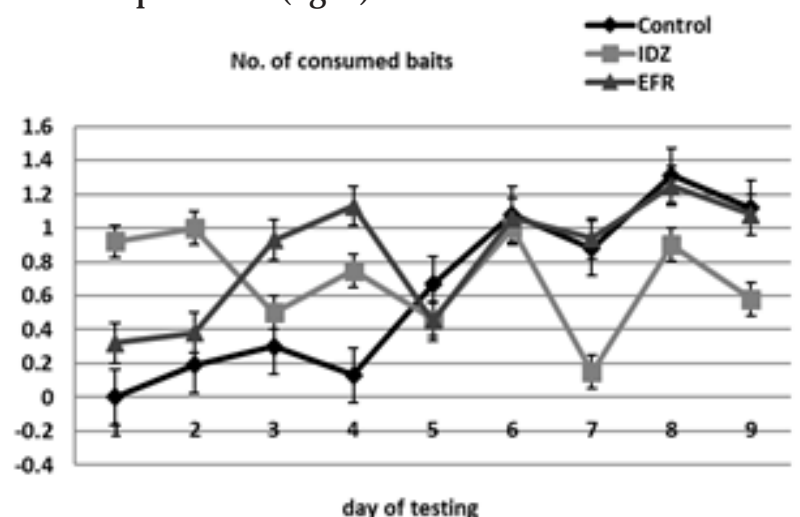

Fig. 3. The influence of IDZ and EFR on the number of consumed baits in radial arm maze test. Values were presented as mean $\pm S D$ of the number of consumed baits
The treatment with IDZ and EFR was accompanied by the decrease in the number of non-baited arms visited, statistically significant $(* * p<0.01)$ compared to control group, at each session of testing (fig. 4). The effects of IDZ on the diminution of the number of arms without food visited, was more powerful than of the EFR in radial arm maze in rats (fig. 4)

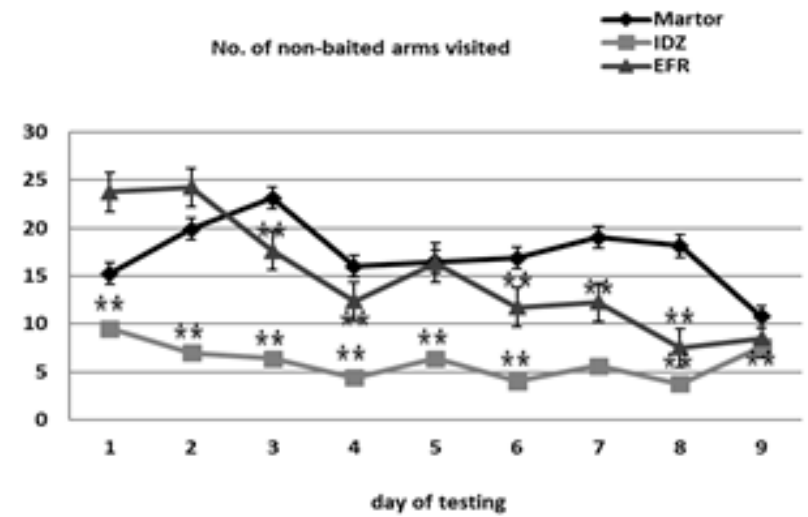

Fig. 4. The influence of IDZ and EFR on the number of non-baited arms visited in radial arm maze test. Values were presented as mean \pm SD of the number of non-baited arms visited

By evaluating the effects of IDZ and EFR in this behavioral test, we obtained information regarding the influence induced by these imidazoline receptors antagonists on the cognitive functions in laboratory animals, particularly on the working and reference spatial memory. We investigated the repercussion of IDZ and EFR administration on the working memory, which give animals the possibility to remember the entries in the arms previously explored; and on the reference memory, which offers animals the option of discriminative chose the arms containing the reward during the sessions of testing.

Using this standardized behavioral model, it was shown that the administration of idazoxan and efaroxan was associated with the decrease in the number of baited arms visited, but previously explored, which corresponds to an improving of the short-term and the discriminative spatial memory. In addition, we demonstrated that the treatment with these two imidazoline receptors antagonists was accompanied by the reducing the number of entries into the arms without food, suggesting the facilitation of longterm memory in radial arm maze in rats. The activity of idazoxan on the investigated parameters was more intense than of efaroxan on the same moments of testing in the experiment.

In the lastyears, several neuro-pharmacological studies regarding the involvement of $\mathrm{I}_{2}$ imidazoline receptors in modulation of behavior, cognitive functions and motor activity were focused on the research of two $I_{1}, I_{2}$ imidazoline and alpha 2 adrenergic receptors antagonists: efaroxan and idazoxan [26]. A new (+) 2- (Ethyl-2,3dihydrobenzofuranyl)-2-imidazoline derivative dexefaroxan, the $(+)$ enantiomer of efaroxan, a potent and selective á2 antagonist, has demonstrated a facilitator effect on the cognitive functions in the passive avoidance test, in rats with scopolamine-induced memory deficit [2730]. Moreover, dexefaroxan showed to increase the memorizing performance in passive avoidance test, to improve the spatial memory in Morris swimming test in rats, and to increase the performance of the object recognition, in the specific behavior model in mice [3134]. It also improves the cognitive functions in knockout mice with Alzheimer disease [35].

Other researches evaluated the effects of agmatine on the memory alterations, similar to those produced in 
Alzheimer's disease, where the fragment Aâ2 25-35 of beta amyloid (the neurotoxic component of beta amyloid Aß 142), plays a crucial role in the pathogenesis of this degenerative disorder (causing cognitive deficits in rodents). It was proved that agmatine significantly reduced the disturbances in spatial learning and memory, induced by beta amyloid fragment Aâ2 25-35, in different behavioral models, such as swimming test, radial arm maze and the object recognition test [36]. It was also, revealed that, agmatine prevented the alteration of lipopolysaccharideinduced spatial memory in swimming test in rats [27]. Moreover, agmatine was found to diminish the activation of caspase-3 in the hippocampus (considered to be an indicator of neuronal apoptosis), caused by lipopolysaccharide, thus suggests its neuroprotective effects [37,38].

The use of selective $I_{1}$ imidazoline and of alpha 2 adrenergic receptors agonist moxonidine, demonstrated the evident recovery of cognitive functions in rats with Huntington's disease, experimentally induced by 3nitropropionic acid (3-NPA), in Morris swimming test and in elevated plus maze, respectively the improvement of learning ability, memory and of the biochemical disturbances [3]. These findings suggest that the substances modulating the activity of I1 imidazoline receptors may be potential agents for the treatment of degenerative brain disorders.

The treatment with moxonidine and clonidine, significantly attenuated the learning and memory deficits, diminished the brain damage, reduced the oxidative stress and the activity of the central cholinesterase. The results suggest the beneficial role of these agonists of imidazoline receptors on vascular dementia induced by the subacute ischemia in the brain $[11,39,40]$.

\section{Conclusions}

In our experimental conditions, the administration of the imidazoline receptors antagonists idazoxan and efaroxan resulted in short-term memory retention enhancement, an improvement of discriminative spatial learning, and a facilitation of long-term memory in radial arm maze in rats.

\section{References}

1.LI, J.X., Pharmacol Ther, 2017, 178: 48-56.

2.NECHIFOR, M,, Medical-Surgical J ournal, 2001, 105(3): 438-443.

3.GUPTA, S., SHARMA, B., Brain Res Bull, 2014, 102: 57-68.

4.SMITH, K.L., JESSOP, D.S., FINN, D.P., Stress, 2009, 12(2): 97-114.

5.CIUBOTARIU, D., NECHIFOR, M., Medical-Surgical Journal, 2012, 116(4): 1118-1122.

6.BILD, V., ABABEI, D.C., NEAMTU, M., VASINCU, A., BILD. W., STANCIU, G.D., TAMBA, B.I., SOLCAN, G., BESCHEA CHIRIAC, S., Farmacia, 2017, 65(4):563-566.

7.GAVRILOVICI, C., LUCA, A., ANTONIU, S.A., GALLABY, K., STEFANESCU, R., STARCEA, M., MIRON, I., BILD, V., Farmacia, 2018, 66(2):197-208.

8.KINO, Y., TANABE, M., HONDA, M., ONO, H., J Pharmacol Sci, 2005, 99(1):52-60.

9.RUSU, G., LUPUSORU, C.E., MITITELU TARTAU, L., POPA, G., BIBIRE, N., LUPUSORU, R.V., CRISTOFOR, A.C., NECHIFOR, M., Farmacia, 2015, 63(2):206-210.

10.DIXIT, M.P., THAKRE, P.P., PANNASE, A.S., AGLAWE, M.M., TAKSANDE, B.G., KOTAGALE, N.R., EurJ Pharmacol, 2014, 732:26-31. 11.LU, Z., LI, C., ZHOU, M., LUO, P., HUANG, P., TAN, J., LU, Q., XU, X., HE, Z., GUO, L., Pharmacol Biochem Behav, 2015, 132: 96-102.
12.KOTAGALE, N.R., TRIPATHI, S.J ., AGLAWE, M.M., CHOPDE, C.T., UMEKAR, M.J., TAKSANDE, B.G., Pharmacol Biochem Behav, 2013, 107:42-47.

13.ARCHIBALD, K., J Anim Ethic, 2018, 8(1):1-11.

14.ALEXA, T., LUCA, A., DONDAS, A., BOHOTIN, C.R., Experimental and Therapeutic Medicine, 2015, 9(4):1465-1469.

15.BRINKMAN, D.J ., TICHELAAR, J., OKORIE, M., BISSELL, L., CHRISTIAENS, T., LIKIC, R., MACIULAITIS, R., COSTA, J., SANZ, E.J ., TAMBA, B.I., MAXWELL, S.R., RICHIR, M.C., VAN AGTMAEL, M.A., Clinical pharmacology \& therapeutics, 2017, 102(5):815-822.

16.DOBRIN, R., CIOBICA, A., TOADER, E., POROCH, V., Rev Chim (Bucharest), 67, no.9, 2016, p. 1778-1782.

17.ALEXA, A.I., CANTEMIR, A., ANTIOCH, I., BALMUS, I.M., COJOCARU, S., GARDIKIOTIS, R., LUCA, A., FILIP, M-A., ABABEI, D.C., ZAMFIR, C.L., Rev Chim (Bucharest), 68, no.2, 2017, p.350-353.

18.MAZUR, J.E., Learning and behavior, Hardcover, $6^{\text {th }}$ Edition, NY, 2006.

19.DE LORENZIS, F., J ournal of Learning and Motivation, 2009, 47(1), 9: 35-50.

20.COLE, M.R., Chappell-Stephenson R, Learn Behav, 2003, 31(4): 349-368.

21.BROWN, M.F., GARY, W.G., Learn Behav, 2006, 34(1): 102-108.

22.TAMBA, B.I., LEON, M.M., PETREUS, T., J Neurosci Res, 2013, 91:554-561.

23.BABB, S.J., CRYSTAL, J.D., Behav Process, 2003, 64, 103-111.

24.DUBREUIL, D., TIXIER, C., DUTRIEUX, G., EDELINE, J.M., Neurobiol Learn Mem, 2003, 79(1): 109-117.

25.ABABEI, D.C., BESCHEA CHIRIAC, S., BILD, W., SOLCAN, C., LUCA, A., RUSU, R.N., BULEA, D., BILD, V., Farmacia, 2017, 65(5):726-730.

26.FERRY, B., PARROT, S., MARIEN, M., LAZARUS, C., CASSEL, J.C., MCGAUGH, J.L., Psychoneuroendocrinol, 2014, 51: 68-79.

27.IVAN, M.V., ZALA, A., AGOP, A., PUIU, E., VÃIDEANU, D., PALAMACIUC, I., TEODOR IANCU, D., CRISAN-DABIJA, R., U.P.B. Sci. Bull., 2017. Series A, Vol. 79, Iss. 3.

28.CHOPIN, P., COLPAERT, F.C., MARIEN, M., J Pharmacol Exp Ther, 2001, 301(1): 187-196.

29.CHOPIN, P., DEBEIR, T., RAISMAN-VOZARI, R., COLPAERT, F.C., MARIEN, M.R., Exp Neurol, 2004, 185(1): 198-200.

30.STANCIU, G.D., SOLCAN, G., BMC veterinary research, 2016, 12:111. 31.PAUWELS, P.J., COLPAERT, F.C., Br J Pharmacol, 2000, 131: 13851390.

32.PAUWELS, P.J., RAULY, I., WURCH, T., JPET, 2003, 305(3): 10151023.

33.DEBEIR, T., MARIEN, M., FERRARIO, J., Exp Neurol, 2004, 190(2): 384-395.

34.URITU, C.M., MIHAI, C.T., STANCIU, G-D., DODI, G., ALEXASTRATULAT, T., LUCA, A., LEON-CONSTANTIN, M.M., STEFANESCU, R., BILD, V., MELNIC, S., TAMBA, B.I., Pain Research \& Management, 2018, 7801543.

35.FRANCIS, B.M., YANG, J., HAJDERI, E., BROWN, M.E., MICHALSKI, B.,MCLAURIN, .,FAHNESTOCK,M.,MOUNT,H.T., Neuropsychopharmacol, 2012, 37(8): 1934-1944.

36.BERGIN, D.H., LIU, P., Neurosci, 2010, 169(2): 794-811.

37.ZARIFKAR, A., CHOOPANI, S., GHASEMI, R., NAGHDI, N., MAGHSOUDI, A.H., MAGHSOUDI, N., RASTEGAR, K., MOOSAVI, M., Eur J Pharmacol, 2010, 634(1-3): 84-88.

38.MATHEUS, F.C., AGUIAR, A.S., JR., CASTRO, A.A., VILLARINHO, J.G., FERREIRA, J., FIGUEIREDO, C.P., WALZ, R., SANTOS, A.R., TASCA, C.I., PREDIGER, R.D., Behav Brain Res, 2012, 235(2): 263-272.

39.HAULICA, I., BILD, W., MIHAILA, C., SERBAN, D.N., SERBAN, L., BOISTEANU, D., IONITA, T., RADASANU, O., J Renin Angiotensin Aldosterone Syst. 2004, 5(2):79-83.

40.GUPTA, S., SHARMA, B., Eur J Pharmacol, 2014b, 723: 80-90.

$\overline{\text { Manuscript received:14.08.2018 }}$ 